第 16 回学術集会

International Session
平成 3 年 6 月 18 日（火)・19 日（水）

虎ノ門パストラル（東京農林年金会館）

Nutritional Support in 1990's

司会 新潟大学外科 武藤 輝一

フロリダ大学外科 WW Souba

\title{
ISI-5 Effect of Administered Human Growth Hormone on Protein Metabolism in Septic Rats
}

\author{
Toshitada Okuma, M. D., Kenji Okamura, M. D.,
}

Yoshimasa Miyauchi, M. D.

1st Department of Surgery

Kumamoto University Medical School

Key word: growth hormone, sepsis, protein metabolism

It is well known that growth hormone $(\mathrm{GH})$ is anabolic agent which effects on the metabolism of lipid, carbohydrate, and protein ${ }^{1,2}$. Especially GH stimulates protein metabolism and accumulates positive nitrogen balance. Although nitogen sparing effect of GH has been examined for healthy subjects, burned patients and the patients with elective surgery ${ }^{3,4,5}$, there are only a few papers described for the effect on septic condition ${ }^{6,7)}$.

In order to estimate the effect of recombinant human growth hormone (HGH) on protein metabolism in septic condition, two experimental studies were designed using sepsis models induced by cecal ligation and induced by administration of endotoxin to rats.

\section{Experimental Design I}

Wistar male rats weighing about $230 \mathrm{~g}$ were used.

After 24 hours of fasting, silastic catheter was inserted into the superior vena cava via the right jugular vein for administration of TPN solution. Rats were divided into 4 groups. Group I $(n=10)$ underwent sham operation. In Group II $(n=14)$, Group III $(n=7)$ and Group IV $(n=10)$, sepsis was induced by cecal ligation without puncture according to Wichterman's method. HGH was administered continuosly every day together with total parenteral nutrition (TPN) infusion to Group III and Group IV. In Group III, a $100 \mathrm{mU} /$ day dose of $\mathrm{HGH}$ was given to each rat and a $200 \mathrm{mU} /$ day dose of $\mathrm{HGH}$ was given to Group IV rats. All rats were maintained in individual metabolic cages and received TPN during the following 4 days. Each rat received $180 \mathrm{kcal} / \mathrm{kg} \cdot$ day of non-protein calories, $1.1 \mathrm{~g} / \mathrm{kg} \cdot$ day of nitrogen $(\mathrm{N})$, minerals and vitamines.

Urine was collected every day for determination of total $\mathrm{N}$ and 3-Methylhistidine (3-MH) excretion. All rats were sacrificed on Day 5. Arterial blood samples were obtained for measurement of blood chemistries. All values were expressed as mean SD, and compaired by student's t-test and analysis of 


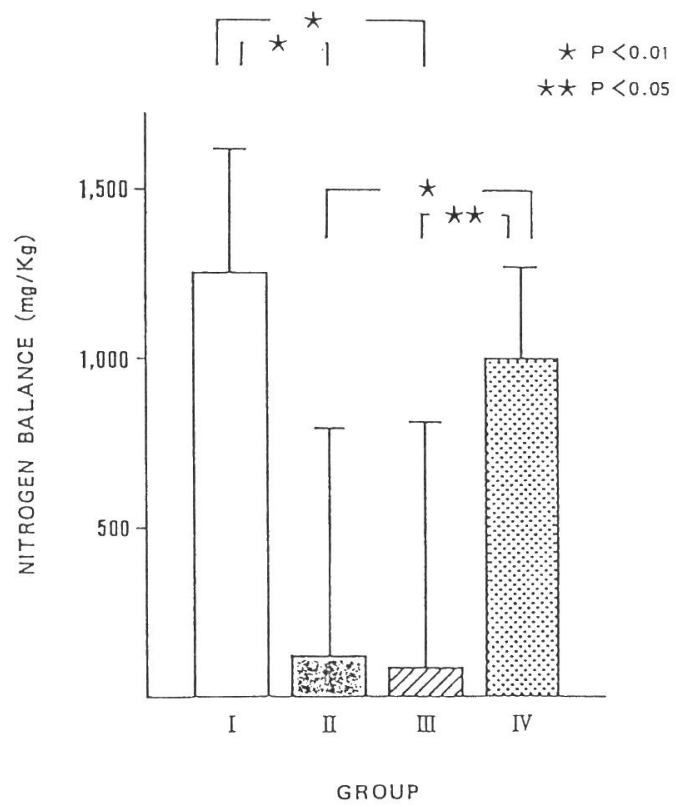

Fig. 1 : Cumulative nitrogen balance of septic rats induced by cecal ligation.

Group I : Control group, non septic rats Group II : septic group without $\mathrm{HGH}$

Group III : Septic group with $100 \mathrm{mU}$ of $\mathrm{HGH}$ Group IV : Septic group with 200 mU of HGH

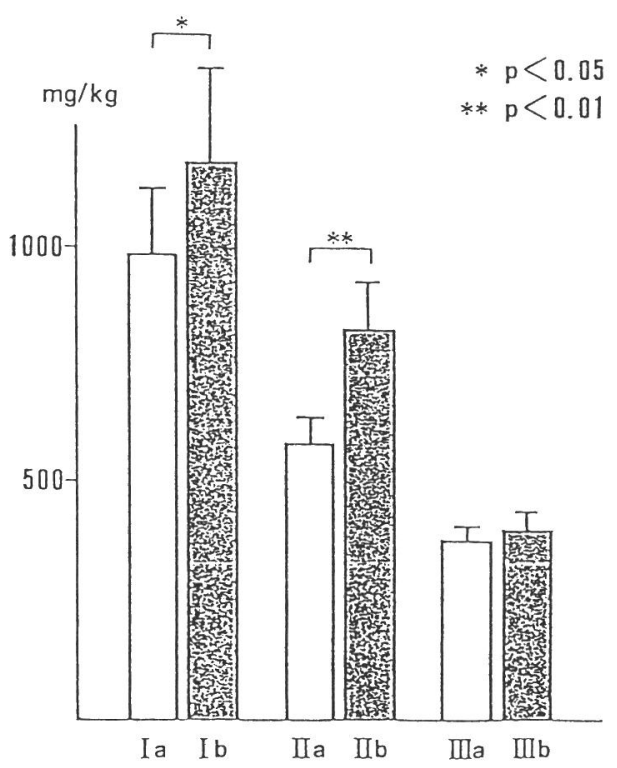

Fig. 2 : Cumulative nitrogen balance of septic rats induced by administration of endotoxin (LPS)

Group I : Control group, non septic rats Group II : Septic group with $1 \mathrm{mg} / 100 \mathrm{~g} \mathrm{B.W}$. of LPS

Group III : Septic group with $2 \mathrm{mg} / 100 \mathrm{~g}$ B.W. of LPS

a : non $\mathrm{HGH}, \mathrm{b}: 200 \mathrm{mU}$ of $\mathrm{HGH}$

variance (ANOVA). Significance was designated at the $95 \%$ confidence level.

\section{Results}

I . Protein Metabolism: Cumulative $\mathrm{N}$ balance during 4 day's course of TPN is shown in Fig-1 : Group- I , $1264 \pm 355$ mg/kg; Group-II, $117 \pm 693$ mg/kg; Group III, $92 \pm 735$ mg/kg; Group-IV, $1001 \pm 279$ $\mathrm{mg} / \mathrm{kg}$. Remarkable improvement was seen in Group-IV compairing with Group-II $(\mathrm{P}<0.01)$, however no improvement was seen in Group-III.

The cumulative urinary excretion of 3-MH in Group I was $6.2 \pm 0.9 \mathrm{mg} / \mathrm{kg}$ and in Group II, Group III and Group IV were $12.0 \pm 2.2 \mathrm{mg} / \mathrm{kg}, 13.4 \pm 2.9 \mathrm{mg} / \mathrm{kg}$ and $10.5 \pm 2.3 \mathrm{mg} / \mathrm{kg}$, respectively. Urinary excretions of 3-MH were significantly higher in all sepsis groups than in sham-operated group, however no significant difference was seen between Group II and Group IV.

II. Blood Chemistries: Serum albumin levels were significantly lower in all sepsis groups than in sham operated groups. The blood urea nitrogen (BUN) in group IV was significantly lower than that in Group II.

The serum levels of blood glucose, insulin, free fatty acid and ketone bodies in Group II and Group III were significantly higher than that in Group I , however there was no difference among sepsis groups. The serum level of HGH was not detected in Group I and Group II.

These data showed that although exogenously administered HGH was effective on protein metabo- 


\section{第 16 回学術学会 International Session Growth Hormone in Sepsis}

lism in septic rats, high dose of $\mathrm{HGH}$ was required to improve $\mathrm{N}$ balance. According to this results, we examined the effects of exogenously administered high dose of HGH on protein metabolism in different severity of septic conditions induced by administration of endotoxin (LPS).

\section{Experimental Design ॥}

Wistar male rats weighing about $230 \mathrm{~g}$ were used and they received 4 days TPN as mention as preveously. Rats were devided to three groups. Group I was control Group without administration of endotoxin. Endotoxin (LPS, E. Coli 025: B6, Sigma Chemical Co.) was administered continuously on 2nd, 3rd and 4th day of study together with TPN infusion to Group II and Group III.

In Group II, a $1 \mathrm{mg} / 100 \mathrm{~g}$ body weight dose of LPS was given to each rat and a $2 \mathrm{mg} / 100 \mathrm{~g}$ body weight dose of LPS was given to Group III rats.

Each group was devided to two subgroups with or without administration of $\mathrm{HGH}$.

A $200 \mathrm{mU} /$ day dose of $\mathrm{HGH}$ was administered continuously together with TPN infusion.

Urine was collected on the 3rd and 4th day to determine total nitrogen and 3- $\mathrm{MH}$, excretion.

Whole body protein kinetics was measured on the 4 th day of the study using a primed continuous infusion of ${ }^{15} \mathrm{~N}$ glycine over $24 \mathrm{hrs}$. according to the Picou \& Taylor-Roberts method.

On day 5 , rats were sacrificed and arterial blood samples were obtained for measurements of blood chemistries.

\section{Results}

I . Protein Metabolism: The cumulative $\mathrm{N}$ balance of the latter 2 days of the study was shown in Fig. 2: Group Ia ( $\mathrm{n}=10$ : Control group and non $\mathrm{HGH}$ rats); $986.5 \pm 150.3 \mathrm{mg} / \mathrm{kg}$, Group I b $(\mathrm{n}=10$ : control group, HGH rats) ; $1183.5 \pm 201.9 \mathrm{mg} / \mathrm{kg}$, Group II a $(\mathrm{n}=8: 1 \mathrm{mg} / 100 \mathrm{~g}$ B.W. of LPS, non HGH rats) ; $584.9 \pm 52.2 \mathrm{mg} / \mathrm{kg}$, Group II b ( $\mathrm{n}=8: 1 \mathrm{mg} / 100 \mathrm{~g} \mathrm{~B}$. W. of LPS, HGH rats) ; $825.9 \pm 100.8 \mathrm{mg} / \mathrm{kg}$, Group III a $(\mathrm{n}=8: 2 \mathrm{mg} / 100 \mathrm{~g}$ B. W. of LPS, non HGH rats) $373.1 \pm 37.9 \mathrm{mg} / \mathrm{kg}$, Group III $\mathrm{b}(\mathrm{n}=7: 2$ $\mathrm{mg} / 100 \mathrm{~g} \mathrm{~B}$. W. of LPS, HGH rats) ; $398.2 \pm 45.8 \mathrm{mg} / \mathrm{kg}$. Group I showed the best $\mathrm{N}$ balance and Group III showed the worst. The cumulative $\mathrm{N}$ balances of $\mathrm{HGH}$ rats were significantly higher than that of non HGH rats in Group I and in Group II, wherease in Group III there was no difference between in HGH rats and in non $\mathrm{HGH}$ rats.

The cumulative urinary excretion of 3-MH showed the highest excretion in Group III of the three groups. However, $\mathrm{HGH}$ was not effective on decreasing of urinary excretion of 3-MH.

II. Blood Chemistries: The serum levels of total protein and albumin showed the lowest level in Group III of the three groups, however there was no significant difference between HGH rats and non HGH rats.

The serum levels of BUN showed the highest level in Group III. In Group II, the level of the HGH rats was significantly lower than that of the non $\mathrm{HGH}$ rats $(\mathrm{p}<0.05)$. The serum glucose levels of $\mathrm{HGH}$ rats were higher than that of non HGH rats, however there was no significant difference. There was no difference in serum riglyceride levels among each group, however the serum levels of free fatty acid in Group I and Group II were significantly higher in $\mathrm{HGH}$ rats than in non $\mathrm{HGH}$ rats. $(\mathrm{p}<0.05, \mathrm{p}<0.01$ respectively).

III. Whole Body Protein Kinetics: The whole body protein turnover rate, breakdown rate and synthesis rate were the most accelerated in Group III of the three groups. The whole body protein turnover rate and breakdown rate were no significant difference between $\mathrm{HGH}$ rats and non $\mathrm{HGH}$ rats. The whole body protein synthesis rate was shown in Fig-3. In Group I and Group II, the whole body 


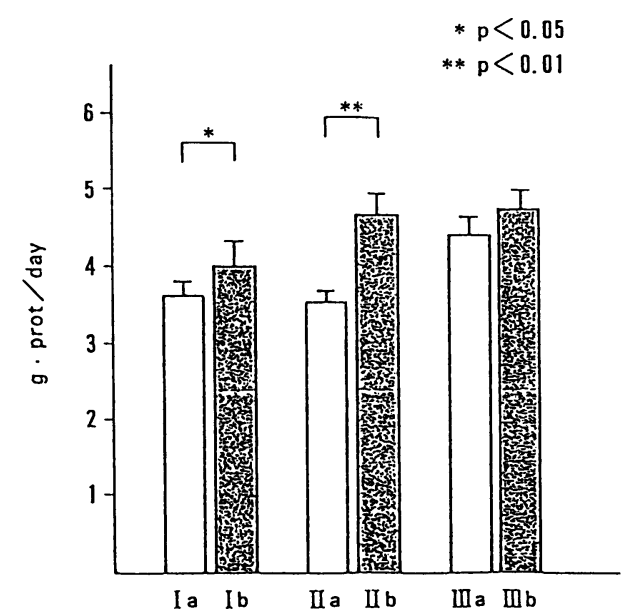

Fig. 3 : Whole body protein synthesis rate of septic rats induced by administration of endotoxin (LPS)

protein synthesis rate of $\mathrm{HGH}$ rats was significantly higher than that of non $\mathrm{HGH}$ rats, wherease in Group III there was no difference between HGH rats and non HGH rats (Fig. 3).

\section{Discussion}

The goal of nutritional support is an improvement of protein metabolism. It is very hard to gain nitrogen retaining in critically illed patients, in spite of receiveing high energy and nitrogen. Especially patients faile to retain positive $\mathrm{N}$ balance in acute phase of septic condition. Shaw reported that net protein catabolism was accelerated when nitrogen more than $1.5 \mathrm{~g} / \mathrm{kg}$ per day was administered to the patients with sepsis ${ }^{8}$. In septic condition, whole body protein kinetics are accelerated. HGH increases tissue amino acid incorporation and results in stimulation of protein synthesis. There are many reports about the effect of HGH on protein metabolism in burned, traumatized and surgical patients. However there are only a few papers for septic condition.

In our studies, high dose of $\mathrm{HGH}$ ( $200 \mathrm{mU} /$ body) was required to improve $\mathrm{N}$ balance in rats with mild septic condition. The dose is as same as $0.8 \mathrm{IU} / \mathrm{kg} \cdot \mathrm{day}(0.32 \mathrm{mg} / \mathrm{kg} \cdot$ day $)$.

In our experimental design II, exogenously administered high dose of $\mathrm{HGH}$ failed to improve nitrogen retaining effect for the rats with severe sepsis induced by $2 \mathrm{mg} / 100 \mathrm{gB}$. W. dose of LPS administration. Why does not work HGH on protein metabolism in severe septic condition? A several mechanisms can be speculated. The first mechanism is thought that $\mathrm{HGH}$ stimulate positive nitrogen balance as a direct action of lipolysis, however fat could not be mobilized in sever sepsis. In our studies, serum FFA levels in severe sepsis were not significantly different between in HGH rats and in non HGH rats. The second mechanism is considered that the sensitivity of $\mathrm{HGH}$ receptor may be altered or decreased in severe septic condition as like as mentioned about insulin receptor. The third mechanism is speculated that although HGH stimulates the production of insulin-like-growth factor-1 (IGF-1) by liver and results in acceleration of protein synthesis as an indirect action, IGF-1 may be not produced by liver in severe septic condition. Dahn reported that IGF-1 production was inhibited in human sepsis administering of $4 \mathrm{mg} /$ day (10 IU/day) of HGH for 48 hours $^{9}$.

In our studies, we have no data to explain this mechanism. Farther studies are necessary. 


\section{Conclusion}

1) High dose of $\mathrm{HGH}$ was required to improve nitrogen balance (N. B.) in septic rats. In severe sepsis, N. B. was not improved, in spite of administration of high dose of HGH.

2) HGH had no effect on decreasing urinary excretion of 3-methylhistidine.

3) Nitrogen sparing effect of $\mathrm{HGH}$ results from a increased whole body protein synthesis rather than a decreased whole body protein breakdown.

4) Careful consideration should be taken for administration of HGH in septic patients.

\section{Reference}

1) Roe CF, \& Kinney J. M. The influence of human growth hormone on energy sources in convalescence Surg Forum $13: 369-371,1962$

2) Henneman D. H. \& Henneman P. H. Effects of human growth hormone on levels of blood and urinary carbohydrate and fat metabolites in man J. Clin. Invest. $39: 1239-1245,1960$

3) Wilmore D. W., Moylan J. A. Bristow B. F. et al. Anabolic effects of human growth hormone and high caloric feedings following thermal injury Surg Gynecol \& Obstet 138: 875-883, 1974

4) Manson J. M. \& Wilmore D. W. Positive nitrogen balance with human growth hormone and hypocaloric intravenous feeding Surgery $100: 188-197,1986$

5. Manson J. M. Smith R. J. Wilmore D. W. Growth hormone stimulates protein syntesis during hypocaloric parenteral nutrition Ann Surg 208: 136-142, 1988

6) Ziegler T. R. Young L. S., Ferrave-Baliviera E. et al. Use of human growth hormone combined with nutritional support in a critical care unit. JPEN $14: 574-581,1990$

7) Okamura K. Okuma T. Tabira Y. et al. Effect of administered human growth hormone on protein metabolism in septic rats JPEN 13: 450-454, 1989

8) Shaw J. F, Wildbore M. \& Wolfe R. R. Whole body protein kinetics in severely septic patients Ann Surg 205: 288-294, 1987

9) Dahn M. S, Lange M. P. \& Jacob L. A. Insulin like growth factor 1 production is inhibited in human sepsis 